\title{
Combined selection for adaptability, genotypic stability and cowpea yield from mixed models
}

\author{
Derivaldo Pureza da Cruz $^{1^{*}}$ (i) Geraldo de Amaral Gravina ${ }^{1}$ Marcelo Vivas $^{1}$ \\ Geovana Cremonini Entringer ${ }^{1}$ Yure Pequeno de Souza ${ }^{1}$ Richardson Sales Rocha ${ }^{1}$ \\ Mário Euclides Pechara da Costa Jaeggi ${ }^{1}$ Dalcirlei Pinheiro Albuquerque ${ }^{1}$ \\ Antônio Teixeira do Amaral Junior ${ }^{1}$ Lília Marques Gravina ${ }^{1}$ \\ Maurisrael de Moura Rocha ${ }^{2}$ Rita de Kássia Guarnier da Silva ${ }^{1}$
}

${ }^{1}$ Centro de Ciências e Tecnologias Agropecuárias, Universidade Estadual do Norte Fluminense (UENF), 28013602, Campos dos Goytacazes, RJ, Brasil. E-mail: deri.engineer@gmail.com. "Corresponding author.

${ }^{2}$ Embrapa Meio-Norte, Teresina, PI, Brasil.

\begin{abstract}
The potential expression of crop productivity is a constant challenge for plant breeders in the face of oscillations in environmental variables, making selection difficult and increasing the operational and methodological costs in obtaining the ideal cultivar for a determined region. The objective of the research was to investigate the effects of genotype $x$ environment interaction in the selection of cowpea lines with high grain yield, adaptability, and genotypic stability simultaneously, in environments of the Northwest region of Rio de Janeiro State, using mixed models (Maximum Restricted Likelihood - REML/Best Linear Unbiased Prediction - BLUP). 27 cowpea genotypes were evaluated in six environments by combining location (Cambuci-RJ and Bom Jesus do Itabapoana-RJ) and year (2016, 2017 and 2018). A randomized block design with four replications was performed. The genetic parameters were estimated via the REML/BLUP procedure, and the selection was based on the harmonic mean method of the relative performance of the genetic values (HMRPGV). A meaningful difference was observed for environment and genotype $x$ environment interaction. The residual variance and the variance of the genotype $x$ environment interaction formed the most significant fractions of the phenotypic variance. Lines 4 (Bico-de-ouro 1-5-24), 6 (Pingo-de-Ouro 1-5-4), 5 (Pingo-de-Ouro 1-5-26), and 9 (Pingo-de-Ouro 1-5-8), stood out as superior in terms of stability and adaptability and grain yield by HMRPGV.Commercial cultivars 13 (BRS-Tumucumaque) and 26 (BRS-Itaim) had high grain yield, adaptability, and specific stability in the evaluated edaphoclimatic conditions. Key words: Vigna unguiculata (L.), genotype x environment interaction, heritability, genetic gain.
\end{abstract}

Seleção combinada para adaptabilidade, estabilidade genotípica e produtividade de feijão-caupi a partir de modelos mistos

RESUMO: A expressão potencial da produtividade das culturas constitui um desafio constante aos criadores de plantas frente às oscilações das variáveis ambientais, dificultando a seleção e onerando os custos operacionais e metodológicos na obtenção da cultivar ideal para determinada região. O objetivo do trabalho foi investigar os efeitos da interação genótipos x ambientes na seleção de linhagens de feijão-caupi com alta produtividade de grãos, adaptabilidade e estabilidade genotípica simultaneamente, em ambientes da região Noroeste do estado do Rio de Janeiro, usando modelos mistos (Máximo Verosimilhança Restrita - REML/Melhor Predição Linear não Viesado - BLUP). Avaliouse 27 genótipos de feijão-caupi em seis ambientes pela combinação de local (Cambuci-RJ e Bom Jesus do Itabapoana-RJ) e ano (2016, 2017 e 2018). Foi utilizado o delineamento em blocos casualizados com quatro repetições. Os parâmetros genéticos foram estimados via procedimento REML/BLUP, e a seleção baseou-se no método da média harmônica do desempenho relativo dos valores genéticos (HMRPGV). Observou-se diferença significativa para ambiente e interação genótipo x ambiente. A variância residual e a variância da interação genótipo $x$ ambiente formaram as maiores frações da variância fenotípica. As linhagens 4 (Bico-de-ouro 1-5-24), 6 (Pingo-de-ouro 1-5-4), 5 (Pingode-ouro 1-5-26) e 9 (Pingo-de-ouro 1-5-8) foram classificadas como superiores quanto a estabilidade e adaptabilidade e rendimento de grãos pelo critério da HMRPGV. As cultivares comerciais 13 (BRS-Tumucumaque) e 26 (BRS-Itaim) reuniram elevada produtividade de grãos, adaptabilidade e estabilidade específica nas condições edafoclimáticas avaliadas.

Palavras-chave: Vigna unguiculata (L.), interação genótipo x ambiente, herdabilidade, ganho genético.

\section{INTRODUCTION}

The cowpea (Vigna unguiculata (L.) Walp.), is a widely adaptable species, high productive capacity, rich in vitamins and minerals and abundant genetic variability (FREIRE FILHO, 2011). In addition, it is a culture of great current and strategic potential, with an excellent perspective on the international market, as it is staple food in more than 65 countries (SINGH et al.,2002; FREIRE FILHO et al.,2011).

Its cultivation occupies an area of approximately one million hectares throughout the national territory, with the North and Northeast 
regions accounting for $90 \%$, enabling the generation of employment and income (SANTOS et al., 2017; PEREIRA et al., 2014).

Second FAO (2018), world production of cowpea is approximately 7 million tons, produced on 12.4 million hectares. The largest producers are Nigeria with 2.5 million tons, Niger with one million tons, and Brazil appears in the third position with 848.3 thousand tons. The Midwest, CenterSouth, Southeast and North regions have the highest production, due to its large-scale cultivation, making use of advanced technologies, notably in the offseason of other crops (RODRIGUES et al., 2017; CONAB, 2018).

In the processes of development and creation of cowpea cultivars, breeders need to test several candidate strains in the field annually, through tests of productivity competition, for several years and in different locations, a practice that certified the commercialization of these productivity strains. superior (BARROS et al., 2013; SANTOS et al., 2014a; TORRES et al., 2015). However, because they are different environments, there is an interaction between genotype and environment ( $\mathrm{G} \times \mathrm{E})$, causing a change in the classification of superior genotypes in the different environments tested (OLIVEIRA et al., 2018), reducing the selection gain.

In this context, it is necessary to estimate the magnitude and nature of the interaction $(\mathrm{G} \times \mathrm{E})$, which allows us to infer about the real assessment and reliability regarding the recommendation of these strains for a given production site or environment (ROSADO et al., 2012).

The simple analysis of the $\mathrm{G} x \mathrm{E}$ interaction does not provide adequate information about the behavior of each strain in the different environments analyzed. Thus, it is necessary to carry out analyzes of adaptability and phenotypic stability, through which it is possible to identify strains with predictable behavior, responsive to environmental variations, under specific or broad conditions (CRUZ et al., 2014; BARILI et al., 2015; TORRES et al., 2015; CARVALHO et al., 2016). In this sense, selection methodologies that include stability and adaptability in the same statistical approach can be considered superior, since it does not only use production as a selection criterion (RESENDE, 2007).

The REML / BLUP mixed model methodology (Restricted Maximum Likelihood), or maximum restricted likelihood, estimates variance components necessary for the model and BLUP (Best Linear Unbiased Prediction), the best-unbiased predictor, estimates the genotypic value, based on the assumption that the smaller the standard deviation of the genotype behaviour between sites, the higher the harmonic mean of their genotypic values at the test sites. The use of mixed models allows the selection of genotypes for genotypic adaptability, stability and grain yield simultaneously, through the use of the harmonic average of genetic values (HMGV), relative performance of genetic values (RPGV) and the harmonic average of the relative performance of genotypic values (HMRPGV) (RESENDE, 2007).

This methodology has been used satisfactorily by breeding programs in the selection of superior genotypes in perennial crops, such as cashew (MAIA et al., 2009), eucalyptus (ROSADO et al., 2012) and annuals, rice (REGITANO et al., 2013 ), cowpea (TORRES et al., 2016; SANTOS et al., 2016; CARVALHO et al., 2017, TORRES FILHO et al. al., 2017) in several regions.

Although the expansion of cowpea cultivation in recent years has expanded to the Southeast and Midwest regions of Brazil, there are few studies in the literature aiming at the selection of superior genotypes for adaptability and stability of grain productivity in the state of Rio de Janeiro. In this context, this work aimed to investigate the effects of the $\mathrm{G} \times \mathrm{E}$ interaction in the simultaneous selection of cowpea strainsfor high grain yield, adaptability and genotypic stability using REML/BLUP methodology in the Northwest region of Rio de Janeiro.

\section{MATERIALS AND METHODS}

\section{Description of the experimental genotypes}

In this experiment, 23 strains of cowpea from the commercial group "cores" and the commercial group "fradinho" and four commercial cultivars used as controls, evaluated by Embrapa Meio-Norte, were evaluated. These lines are part of the value of cultivation and use (VCU), necessary to register new cultivars by the National Register of Cultivars (NRC) of the Ministry of Agriculture, Livestock, and Supply (MAPA) (Table 1).

\section{Experimental conduct}

The strains were obtained mainly by the descending methods of a single pod (SPD) and genealogical with biennial selection cycles. Advanced lines were selected based on grain yield $\left(\mathrm{kg} . \mathrm{ha}^{-1}\right)$, plant architecture, precocity and grain quality, and disease resistance.

The four commercial cultivars 13 (BRS Tumucumaque), 14)(BRS Imponente), 26 (BRS Itaim) and 27 (CB-27), used as witnesses in the tests 
Table 1 - Identification of the 27 cowpea genotypes (Vigna unguiculata) evaluated in the municipalities of Cambuci and Bom Jesus do Itabapoana-RJ, 2016, 2017 and 2018

\begin{tabular}{|c|c|c|}
\hline Order & Lines code & Commercial subclass ${ }^{(1)}$ \\
\hline 1 & Bico-de-ouro 1-5-11 & SV \\
\hline 2 & Bico-de-ouro 1-5-15 & SV \\
\hline 3 & Bico-de-ouro 1-5-19 & SV \\
\hline 4 & Bico-de-ouro 1-5-24 & ML \\
\hline 5 & Pingo-de-ouro 1-5-26 & ML \\
\hline 6 & Pingo-de-ouro 1-5-4 & ML \\
\hline 7 & Pingo-de-ouro 1-5-5 & ML \\
\hline 8 & Pingo-de-ouro 1-5-7 & ML \\
\hline 9 & Pingo-de-ouro 1-5-8 & ML \\
\hline 10 & Pingo-de-ouro 1-5-10 & ML \\
\hline 11 & Pingo-de-ouro 1-5-11 & ML \\
\hline 12 & Pingo-de-ouro 1-5-14 & ML \\
\hline 13 & BRS Tumucumaque & BR \\
\hline 14 & BRS Imponente & $\mathrm{BC}$ \\
\hline 15 & MNC06-895-1 & FR \\
\hline 16 & MNC06-895-2 & FR \\
\hline 17 & MNC06-901-14 & FR \\
\hline 18 & MNC06-907-29 & FR \\
\hline 19 & MNC06-907-30 & FR \\
\hline 20 & MNC06-907-35 & FR \\
\hline 21 & MNC06-908-39 & FR \\
\hline 22 & MNC06-909-52 & FR \\
\hline 23 & MNC06-909-55 & FR \\
\hline 24 & MNC06-909-68 & FR \\
\hline 25 & MNC06-909-76 & FR \\
\hline 26 & BRS Itaim & FR \\
\hline 27 & CB-27 & FR \\
\hline
\end{tabular}

(1) BR- Branco; BC - Brancão; ML- Mulato; SV- Sempre-verde; FR- Fradinho.

with the strains, come from other states and do not have commercial crops in the state of Rio de Janeiro, being used only for purposes of competition tests during the years of evaluation of the strains.It is important to note that there was no witness for all groups of strains evaluated in the experiments.

The cultivar BRS-Tumucumaque (13) has an architecture that allows mechanized harvesting, medium-sized white grains with excellent commercial acceptance, high productivity and early maturation cycle. The cultivar BRS-Itaim (26) presents mediumsized grains, early maturation cycle, erect plant size, associated with high productivity.

The experiments were performed from May to August in 2016, 2017 and 2018, at the Fluminense Federal Institute, in the municipalities

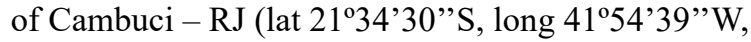
alt 35 mand Bom Jesus do Itabapoana (lat $21^{\circ} 8$ ' $2^{\prime}$ S, $41^{\circ} 40^{\prime} 48^{\prime \prime} \mathrm{W}$, alt $88 \mathrm{~m}$ ), located in the Northwest region of the State of Rio de Janeiro, which have a tropical climate according to the Köppen-Geiger climate classification (ALVARES et al., 2013)

\section{Experimental design}

A randomized block design with four replications was used. The experimental plot consisted of four $3.0 \mathrm{~m}$ long lines, spaced at $0.50 \mathrm{~m}$ between strains and $0.15 \mathrm{~m}$ between plants, considering the two central strains as useful area.

The sowing fertilization consisted of 180 kg.ha ${ }^{-1}$ of mineral fertilizer of the commercial formula 04-14-08, according to the recommendations for the 
crop. One week after seedling emergence, plants were thinned manually, leaving twelve seedlings per meter. The irrigation was carried out by a sprinkler system, and the cultural and phytosanitary treatments were carried out according to (FILGUEIRA, 2013).

\section{Genetic-statistical analyses}

The grain yield data were obtained from competition tests carried out in different environments. To evaluate the effects of the $G \times E$ interaction, in the evaluation of the effects of the $\mathrm{G} x$ E interaction, the statistical model 54 of the SelegenReml/Blupsoftware was adopted, corresponding to $\mathrm{y}=\mathrm{Xb}+\mathrm{Zg}+\mathrm{Wc}+\mathrm{e}$, where $\mathrm{y}$ is the data vector; $b, g, c$ and $e$ correspond to the effects of the blocks added to the overall mean (considering all the replications of all the locations - assumed as fixed), genotypic effects (assumed as random), effects of the $\mathrm{G} \times \mathrm{E}$ interaction (random), and the random errors, respectively; and $\mathrm{X}, \mathrm{Z}$ and $\mathrm{W}$ represent the incidence matrices for the tested effects (RESENDE, 2007). The distributions and structures of means (E) and variances (Var) assumed were:

$$
E\left[\begin{array}{l}
y \\
g \\
c \\
e
\end{array}\right]=\left[\begin{array}{c}
X b \\
0 \\
0 \\
0
\end{array}\right] ; \operatorname{Var}\left[\begin{array}{l}
g \\
c \\
e
\end{array}\right]=\left[\begin{array}{ccc}
I \sigma_{g}^{2} & 0 & 0 \\
0 & I \sigma_{c}^{2} & 0 \\
0 & 0 & I \sigma_{e}^{2}
\end{array}\right]
$$

The adequacy of the model was obtained through the mixed model equations:

$$
\begin{gathered}
{\left[\begin{array}{ccc}
X^{\prime} X & X^{\prime} Z & X^{\prime} W \\
Z^{\prime} X & Z^{\prime} Z+I \lambda_{1} & Z^{\prime} W \\
W^{\prime} X & W^{\prime} Z & W^{\prime} W+I \lambda_{2}
\end{array}\right] \times\left[\begin{array}{c}
\hat{b} \\
\hat{g} \\
\hat{c}
\end{array}\right]=\left[\begin{array}{c}
X^{\prime} y \\
Z^{\prime} y \\
W^{\prime} y
\end{array}\right],} \\
\text { Where, } \lambda_{1}=\frac{\sigma_{e}^{2}}{\sigma_{g}^{2}}=\frac{1-h_{g}^{2}-C^{2}}{h_{g}^{2}} ; \text { in which } h_{g}^{2}=
\end{gathered}
$$
$\frac{\sigma_{g}^{2}}{\sigma_{g}^{2}+\sigma_{c}^{2}+\sigma_{e}^{2}}$, correspond to the individual heritability, in the broad sense for the block; $C^{2}=\frac{\sigma_{C}^{2}}{\sigma_{g}^{2}+\sigma_{C}^{2}+\sigma_{e}^{2}}$ corresponds to the coefficient of determination of the effects of the genotype $\mathrm{x}$ environment interaction; $\sigma_{g}^{2}$ is the genotypic variance between cowpea genotypes; $\sigma_{C}^{2}$ is the variance between genotype x environment interaction; $\sigma_{e}^{2}$ is the residual variance between plots; $\mathrm{r}_{g l o c}=\frac{\sigma_{C}^{2}}{\sigma_{g}^{2}+\sigma_{C}^{2}}=\frac{h_{g}^{2}}{h_{g}^{2}+C^{2}}$, corresponds to the genotypic correlation of genotypes across environments.

The iterative estimators of the variance components, by REML, via EM algorithm, are: $\hat{\sigma}_{e}^{2}$

$$
\begin{aligned}
& =\frac{\left[y^{\prime} y-\hat{b}^{\prime} x^{\prime} y-\hat{g}^{\prime} z^{\prime} y-\hat{c} W^{\prime} y\right]}{[N-r(x)]} ; \hat{\sigma}_{g}^{2}=\frac{\left[\hat{g}^{\prime} \hat{g}+\hat{\sigma}_{e}^{2} t r C^{22}\right]}{q} ; \hat{\sigma}_{c}^{2} \\
& =\frac{\left[\hat{c}^{\prime} c+\hat{\sigma}_{e}^{2} t r C^{33}\right]}{s} ; \text { in which: } C^{2} \mathrm{e} C^{3} \text { come from }
\end{aligned}
$$$$
\left[\begin{array}{lll}
C_{11} & C_{12} & C_{13} \\
C_{21} & C_{22} & C_{23} \\
C_{31} & C_{32} & C_{33}
\end{array}\right]^{-1}=\left[\begin{array}{lll}
C^{11} & C^{12} & C^{13} \\
C^{21} & C^{22} & C^{23} \\
C^{31} & C^{32} & C^{33}
\end{array}\right] \text {, where C }
$$
is the matrix of the coefficients of the mixed model equations; $t r$ is the matrix trace operator; $r(x)$ the rank of matrix $\mathrm{X} ; \mathrm{N}, \mathrm{q}, \mathrm{s}=$ total number of data, number of genotypes, and number of genotype $\mathrm{x}$ environment combinations, respectively.

Through this model, the empirical BLUP predictors (REML / BLUP) of the genotypic values free from the interaction were obtained, given by $\widehat{\mu}+\hat{g}_{i}$, in which $\widehat{\mu}$ is the average of all environments and $\hat{g}_{i}$ it is the free genotype effect of the genotype $\mathrm{x}$ environment interaction. For each environment $j$, the genotypic values $(V)$ are predicted by $\hat{\mu}_{j}+\hat{g}_{i}+(\hat{g} e)_{i j}$ , where $\hat{\mu}_{j}$ is the average of the environment $j$, $\hat{g}_{i}$ is the genotypic effect of genotype $i$, in environment $\mathrm{j}$, and $(\hat{g} e)_{i j}$ is the effect of the $\mathrm{G} \times \mathrm{E}$ interaction relative to genotype $i$.The prediction of genotypic values capitalizing on the average interaction (gem) in different envirnnments is given by $\widehat{\mu}_{j}+\hat{g}_{i}+\hat{g} e_{m}$, accounted by: $\widehat{\mu}+\frac{\left.\frac{\hat{\sigma}_{g}^{2}+\hat{\sigma}_{c}^{2}}{n}\right)}{\hat{\sigma}_{g}^{2}} \hat{\mathrm{g}}_{\mathrm{i}}$,

where $\widehat{\mu}$, it is the general average of all environments; $n$ is the number of environments and $\hat{\mathrm{g}}_{\mathrm{i}}$ is the genotypic effect of genotype $i$.

The following parameters were estimated: genotypic variance $\hat{\sigma}_{g}^{2}$; residual variance between plots $\hat{\sigma}_{e}^{2}$; variance of genotype $\mathrm{x}$ environment interaction $\hat{\sigma}_{g e}^{2}$; phenotypic variance $\hat{\sigma}_{f}^{2}$; Coefficient of determination of the effects of genotype $\mathrm{x}$ environment interaction $C^{2}{ }_{g e} ; \hat{h}_{m g}^{2}$ : average genotype heritability; $\hat{r}_{g g}^{2}$ : selective accuracy; $\hat{r}_{g l o c}$ : genotypic correlation between environments; $C V_{g}$ : Coefficient of genetic variation; $C V$ : Experimental variation coefficient; $\mu$ : overall average. The likelihood ratio test (LRT) was performed in order to test the significance of the random effects of the model, shown in the table of analysis of deviations of the effects (Resende 2016).

According to the proposed model, the genotypic values free from any interaction with the environments were obtained by $(\mu+g i)$, where $\mu$ is the mean of all environments and gi is the free genotype effect of the genotype $\times$ environment interaction. For each environment $j$, the genotypic values were predicted by $\mu+g_{i}+(g e)_{i j}$, where $\mu$ is the mean of environment $j$, $g_{i}$ is the genotypic effect of genotype $i$ in environment $j$, and $(\mathrm{ge})_{\mathrm{ij}}$ is the effect of the interaction $\mathrm{G} \times \mathrm{E}$ in relation to the genotype $\mathrm{i}$ and environment $\mathrm{j}$ (Resende 2007).

Based on cowpea grain yield, the adaptability and stability analyzes were performed 
using the REML / BLUP methodology. In this method, the harmonic mean of the genotypic values (HMGV) estimates the grain stability and productivity directly, simultaneously. Therefore, selection by the values of the HMGV implies selection for productivity and stability. Alternatively, adaptability is estimated by the relative performance of genotypic values (RPGV), between environments. RPGV values indicate the joint selection for productivity and adaptability. While HMRPGV, simultaneously estimates adaptability, stability and productivity, where genotypes are ordered based on their genotypic values. In this context, the following parameters were calculated using the equations: harmonic mean of the genotypic values (HMGV) obtained through the equation $H M G V_{i}=\mathrm{e} / \sum_{j=1}^{e}\left(1 / G V_{i j}\right.$ ), where $\mathrm{e}$ is the number of environments in which genotype $i$ was evaluated, and $G C_{i j}$ is the genotypic value of the genotype $i$ in the environment $j$; relative performance of genotypic values (RPGV) obtained through the expression $R P G V_{i}=(1 / \mathrm{e}) \sum_{j=1}^{e}\left(\mathrm{GV}_{\mathrm{ij}} / \mu_{\mathrm{j}}\right)$, where $\mu_{\mathrm{j}}$ is the environment average $j$; harmonic mean of RPGV (HMRPGV) calculated through the expression

$H M R P G V_{i}=\mathrm{e} / \sum_{j=1}^{e}(1 / R P G V)$ (Resende 2007). The average genotypic value, capitalizing on adaptability, is obtained by RPGV multiplied by the overall average of all environments $\left(R P G V^{*} \mu\right)$, and the average genotypic value penalized by instability and capitalized by stability is calculated by HMRPGV multiplied by the overall average of all environments $\left(H M R P G V^{*} \mu\right)$. All analyzes were performed using the software SELEGEN-REML/ BLUP (Resende 2007, 2016).

\section{RESULTS AND DISCUSSION}

The deviance analysis showed that there was a significant effect for the environment and
$\mathrm{G} \times \mathrm{E}$ interaction by the chi-square test, at $1 \%$ probability. However, there was no significant difference as considering the genotype as a source of variation (Table 2). These results demonstrate that the potential grain yield and grain production of the cowpea strains did not differ genetically and, therefore, did not show a differential response in the environments in the region where the tests were performed. Alternatively, the occurrence of the significance of the environment and the $\mathrm{G} x$ $E$ interaction, influenced by the complexity of the environmental variations, justifies its details through adaptability and stability analyzes (TORRES et al., 2015; AQUINO et al. (2016), found a significant difference for the effects of the $G \times E$ interaction when evaluating 30 cowpea genotypes regarding the adaptability and stability of immature grain yield in the states of Pernambuco and Bahia.

The analysis of the components of variance (REML) highlighted that the environmental variance represented the most significant fraction $(87 \%)$ of the phenotypic variance, followed by the variance of the $\mathrm{G} \times \mathrm{E}$ interaction (12.3), and the genotypic variance (0.7), lower participation observed (Table 3). The individual phenotypic variance is composed by the computation of the genotypic variance, the residual variation between plots and the variation of the genotype $\mathrm{x}$ environment interaction (CARVALHO et al., 2016). The high magnitude of environmental variation over the other components of the phenotypic variation can be explained by the polygenic nature and low heritability of the trait and the fluctuations of the edaphoclimatic variables of each environment (SILVA et al., 2013b; BARILI et al., 2015).Studies reported by (TORRES et al., 2015; ROCHA et al., 2017), in multiple environments, presented a higher proportion of environmental variation concerning the

Table 2 - Summary of the deviance analysis of 27 cowpea genotypes for grain productivity, evaluated in the municipalities of Cambuci and Bom Jesus do Itabapoana, in the years 2016, 2017 and 2018, in the state of Rio de Janeiro.

\begin{tabular}{lcc}
\hline Effect & Deviance & Chi-square $^{(1)}$ \\
\hline Genotypes & 8276.69 & $0.13^{\text {ns }}$ \\
Enveironments & 8287.7888 & $11.2288^{* *}$ \\
Genotype x environment interaction & 8290.5184 & $13.9584^{* *}$ \\
Residue & - & - \\
Complete model & 8276.56 & - \\
\hline
\end{tabular}

${ }^{(1)}$ Deviance model adjusted without the quoted effects; ${ }^{(2)}$ ns, ${ }^{* *}$ Not significant and significant at $1 \%$ probability by the chi-square test. respectively. 
Table 3 - Estimates of genetic parameters (individual REML) of 27 of cowpea genotypes for grain yield, evaluated in the municipalities of Cambuci and Bom Jesus do Itabapoana, in the years 2016, 2017 and 2018, in the state of Rio de Janeiro.

\begin{tabular}{|c|c|}
\hline Genetic parameter & Estimate \\
\hline Genotypic variance $\left(\hat{\sigma}_{g}^{2}\right)$ & 1350.49 \\
\hline Residual variance between plots $\left(\hat{\sigma}_{e}^{2}\right)$ & 166011.82 \\
\hline Variance of genotype $\mathrm{x}$ environment interaction $\left(\hat{\sigma}_{g \varepsilon}^{2}\right)$ & 23521.63 \\
\hline Phenotypic variance $\left(\hat{\sigma}_{f}^{2}\right)$ & 190883.96 \\
\hline Determination coefficient of the interaction $\mathrm{G} \times \mathrm{E}\left(\mathrm{Cgg}_{g \varepsilon}^{2}\right)$ & 0.123 \\
\hline Average heritability of genotypes $\left(\hat{h_{\mathrm{mg}}^{2}}\right)$ & 0.11 \\
\hline Selective accuracy $\left(\hat{r}_{g g}^{2}\right)$ & 0.33 \\
\hline Genotypic correlation between environments $\left(\hat{F}_{\text {gio }}\right)$ & 0.054 \\
\hline Coefficient of genetic variation $\left(C V_{g}\right)$ & 2.78 \\
\hline Experimental variation coefficient $\left(C V_{e}\right)$ & 33.07 \\
\hline Overall Average $(\mu)$ & 1232.02 \\
\hline
\end{tabular}

$\hat{\sigma}_{g}^{2}$ : genotypic variance; $\hat{\sigma}_{e}^{2}$ : residual variance between plots; $\hat{\sigma}_{g e}^{2}$ : variance of genotype x environment interaction; $\hat{\sigma}_{f}^{2}:$ phenotypic variance; $C_{g e}^{2}$ : Coefficient of determination of the effects of genotype x environment interaction; $\hat{h}_{m g}^{2}$ : average genotype heritability; $\hat{r}_{g g}^{2}$ : selective accuracy; $\hat{r}_{g l o c}:$ genotypic correlation between environments; $C V_{g}$ : Coefficient of genetic variation; $C V_{e}$ : Experimental variation coefficient; $\mu$ : overall average.

other phenotypic components when evaluating grain yield in cowpea genotypes.

Heritability based on the average of the genotypes $\left(\hat{h}_{m g}^{2}\right)$ is estimated when using block averages as an evaluation or selection criterion (RESENDE, 2004). The heritability coefficient obtained in the presentstudy, based on the average of the environments, was considered to be of low magnitude (0.11), providing a high observed environmental effect. (Table 3 ). Besides the environmental effects, reduced heritability may be associated with the nature of the character and the low genetic variability of the study population(RAMALHO et al., 1993; TORRES FILHO et al., 2017), observed low heritability (0.4) when evaluating cowpea strains for immature grain yield under environmental and soil conditions in Mossoró-RN.SANTOS et al. (2018), obtained similar heritability when evaluating the adaptability and stability of common bean genotypes for grain yield in environments of the state of Pernambuco, using the methodology (REML/BLUP).

According to CHIORATO et al. (2008), experimental aspects such as the number of repetitions and the number of plants evaluated per plot, influence the estimate of heritability based on the genotypic average. In the present study, this condition may have been unfavourable to suppress environmental effects, as the number of plants evaluated in the useful area of the plot was low, directly influencing the representativeness of the strains.

The coefficient of experimental variation obtained was considered high (33), similar to that found by (BARROS et al., 2013), when they evaluated the adaptability and stability of semiprostrate cowpea genotypes for grain yield in the Northeast region of Brazil.

The selective accuracy, the correlation between the true genotypic value of the genotypes and the estimated or predicted from the data of the experiments, plays a fundamental role in the evaluation of the strains, assuming values ranging from 0 to 1 , with the desired values for experimental precision being closest to the unit (RESENDE \& DUARTE, 2007). The selective accuracy achieved in the present study was $(0.33)$ (Table 3$)$. This estimate is similar to that obtained by (TORRES FILHO et al., 2017), when they obtained an accuracy of (0.20) when evaluating cowpea genotypes for immature grain yield under cultivation conditions in the municipality of Mossoró-RN.

The influence exerted by the interaction component $\mathrm{G} \times \mathrm{E}(23,521.63)$ on the phenotypic variation provided a low phenotypic correlation 
between environments (0.054) (Table 3$)$. In this situation, the $\mathrm{G} \times \mathrm{E}$ interaction is predominantly complex, causing inconsistency in the classification of strainsin the evaluated environments (Tables 4 and 5), making it challenging to select the superior genotypes (RESENDE, 2007).

Given this context, the importance of the analysis of adaptability and stability is unequivocal, to generate reliable and accurate information regarding the selection of cowpea strains for grain productivity with greater predictability. Similar reports of $G x$ $\mathrm{E}$ interaction as a component of most considerable influence on phenotypic variation were found by
(ROCHA et al. 2017), when evaluating the grain yield of 20 cowpea genotypes in Northeast Brazil.

The selection of the best cowpea strains was carried out based on three different methodologies (Tables 4, 5 and 6). According to the estimates of the average components(BLUP) associated with the predicted genotypic value $(\widehat{\mu}+\mathrm{g})$, strains4 (Bicode-ouro 1-5-24), 6 (Pingo-de-ouro 1-5- 4) 5 (Pingode-ouro 1-5-26) and 9 (Pingo-de-ouro 1-5-8) were superior to most of the strains evaluated, presenting the most significant genetic gains compared to the general average, with $104,64 \mathrm{~kg}$ or $8.49 \%, 97.55 \mathrm{~kg}$ or $7.92 \%, 64.90 \mathrm{~kg}$ or $5.27 \%$ and $48.04 \mathrm{~kg}$ or $3.90 \%$

Table 4 - Estimates of predicted genetic gain (BLUP individual) of 27 cowpea genotypes evaluated in the municipalities of Cambuci and Bom Jesus do Itabapoana, considering the average performance of environments in the state of Rio de Janeiro, Brazil.

\begin{tabular}{|c|c|c|c|c|c|c|c|}
\hline Order & Genotype & $\mathrm{g}$ & $\hat{\mu}+\mathrm{g}$ & Gain & New Average & $\hat{\mu}+\mathrm{g}+\mathrm{gem}$ & Overall average \\
\hline 1 & 4 & 23.98 & 1256.01 & 23.98 & 1256.01 & 1336.66 & 1296.34 \\
\hline 2 & 6 & 22.36 & 1254.38 & 23.17 & 1255.19 & 1329.57 & 1292.38 \\
\hline 3 & 5 & 14.87 & 1246.89 & 20.40 & 1252.43 & 1296.92 & 1274.68 \\
\hline 4 & 9 & 11.01 & 1243.03 & 18.05 & 1250.08 & 1280.06 & 1265.07 \\
\hline 5 & 2 & 10.02 & 1242.04 & 16.45 & 1248.47 & 1275.72 & 1262.10 \\
\hline 6 & 3 & 8.58 & 1240.61 & 15.14 & 1247.16 & 1269.48 & 1258.32 \\
\hline 7 & 25 & 6.56 & 1238.58 & 13.91 & 1245.94 & 1260.64 & 1253.29 \\
\hline 8 & 11 & 6.18 & 1238.20 & 12.95 & 1244.97 & 1258.99 & 1251.98 \\
\hline 9 & 18 & 4.00 & 1236.03 & 11.95 & 1243.98 & 1249.49 & 1246.74 \\
\hline 10 & 24 & 3.13 & 1235.16 & 11.07 & 1243.09 & 1245.69 & 1244.39 \\
\hline 11 & 26 & 1.44 & 1233.46 & 10.19 & 1242.22 & 1238.29 & 1240.26 \\
\hline 12 & 13 & 1.19 & 1233.21 & 9.44 & 1241.47 & 1237.21 & 1239.34 \\
\hline 13 & 8 & 0.82 & 1232.85 & 8.78 & 1240.81 & 1235.61 & 1238.21 \\
\hline 14 & 7 & -0.78 & 1231.25 & 8.09 & 1240.12 & 1228.63 & 1234.38 \\
\hline 15 & 10 & -2.54 & 1229.48 & 7.38 & 1239.41 & 1220.92 & 1230.17 \\
\hline 16 & 17 & -2.65 & 1229.38 & 6.76 & 1238.78 & 1220.47 & 1229.63 \\
\hline 17 & 19 & -4.02 & 1228.01 & 6.13 & 1238.15 & 1214.50 & 1226.33 \\
\hline 18 & 20 & -5.29 & 1226.74 & 5.49 & 1237.52 & 1208.95 & 1223.24 \\
\hline 19 & 23 & -5.79 & 1226.23 & 4.89 & 1236.92 & 1206.76 & 1221.84 \\
\hline 20 & 16 & -6.86 & 1225.16 & 4.31 & 1236.33 & 1202.08 & 1219.21 \\
\hline 21 & 14 & -7.39 & 1224.63 & 3.75 & 1235.78 & 1199.77 & 1217.78 \\
\hline 22 & 22 & -10.62 & 1221.40 & 3.10 & 1235.12 & 1185.68 & 1210.40 \\
\hline 23 & 1 & -11.36 & 1220.66 & 2.47 & 1234.49 & 1182.44 & 1208.47 \\
\hline 24 & 21 & -11.92 & 1220.11 & 1.87 & 1233.89 & 1180.03 & 1206.96 \\
\hline 25 & 12 & -12.83 & 1219.19 & 1.28 & 1233.31 & 1176.06 & 1204.69 \\
\hline 26 & 27 & -13.47 & 1218.55 & 0.72 & 1232.74 & 1173.26 & 1203.00 \\
\hline 27 & 15 & -18.62 & 1213.40 & 0,00 & 1232.02 & 1150.77 & 1191.40 \\
\hline Mean & & & & & 1241.35 & 1232.02 & 1236.69 \\
\hline$\hat{\sigma}^{2}$ & & & & & 46.73 & 2176.62 & 714.04 \\
\hline
\end{tabular}

${ }^{(1)}$ Estimates g: genotypic effect; $\hat{\mu}+\mathrm{g}$ : predicted genotypic value; $\mathrm{e} \hat{\boldsymbol{\mu}}+\mathrm{g}+\mathrm{gem}$ : average genotypic value in environments. 
Table 5 - Estimates of the predicted genetic gain of 27 cowpea genotypes for grain yield, evaluated in the municipalities of Cambuci and Bom Jesus do Itabapoana, in the years 2016, 2017 and 2018, in the state of Rio de Janeiro.

\begin{tabular}{|c|c|c|c|c|c|c|c|}
\hline Order & Env 1 & Env 2 & Env 3 & Env 4 & Env 5 & Env 6 & $\widehat{\hat{p}}+\mathrm{g}$ \\
\hline & $\widehat{\mu}+\mathrm{g}+\mathrm{ge}$ & $\hat{\mu}+g+g e$ & $\widehat{\hat{\mu}}+\mathrm{g}+\mathrm{ge}$ & $\hat{\mu}+\mathrm{g}+\mathrm{ge}$ & $\widehat{\mu}+g+g e$ & $\widehat{\mu}+\mathrm{g}+\mathrm{ge}$ & \\
\hline 1 & 1696.45 & 1124.19 & 1037.78 & 1273.85 & 1535.79 & 1351.83 & 1256.01 \\
\hline 2 & 1568.99 & 1215.07 & 828.59 & 1262.01 & 1620.40 & 1482.30 & 1254.38 \\
\hline 3 & 1607.64 & 1176.88 & 987.57 & 1153.62 & 1459.70 & 1396.07 & 1246.89 \\
\hline 4 & 1534.98 & 1086.06 & 897.38 & 1259.42 & 1438.53 & 1463.99 & 1243.04 \\
\hline 5 & 1497.11 & 1227.83 & 825.18 & 1113.29 & 1576.49 & 1414.41 & 1242.04 \\
\hline 6 & 1416.01 & 1231.82 & 916.45 & 1152.89 & 1480.58 & 1419.13 & 1240.61 \\
\hline 7 & 1285.21 & 1186.48 & 1002.98 & 1279.19 & 1481.02 & 1328.93 & 1238.58 \\
\hline 8 & 1417.38 & 1152.55 & 1030.80 & 1097.59 & 1475.33 & 1380.28 & 1238.21 \\
\hline 9 & 1279.22 & 1226.36 & 1016.52 & 1282.29 & 1442.52 & 1250.02 & 1236.03 \\
\hline 10 & 1362.40 & 1100.75 & 898.08 & 1165.58 & 1585.82 & 1361.53 & 1235.16 \\
\hline 11 & 1264.51 & 1179.68 & 1052.76 & 1108.19 & 1505.09 & 1319.49 & 1233.46 \\
\hline 12 & 1572.14 & 1120.76 & 886.86 & 1183.41 & 1335.01 & 1325.06 & 1233.21 \\
\hline 13 & 1501.61 & 1044.15 & 781.73 & 1152.39 & 1538.85 & 1394.94 & 1232.85 \\
\hline 14 & 1518.39 & 1211.87 & 862.89 & 1113.59 & 1416.49 & 1248.52 & 1231.25 \\
\hline 15 & 1434.44 & 1111.85 & 1009.63 & 1137.44 & 1327.28 & 1304.88 & 1229.48 \\
\hline 16 & 1367.89 & 1125.77 & 955.98 & 1108.95 & 1482.15 & 1282.11 & 1229.38 \\
\hline 17 & 1302.99 & 1221.89 & 870.19 & 1263.93 & 1444.13 & 1183.88 & 1228.01 \\
\hline 18 & 1249.60 & 1168.95 & 915.43 & 1195.09 & 1430.88 & 1293.78 & 1226.74 \\
\hline 19 & 1385.42 & 1155.19 & 809.21 & 994.24 & 1590.58 & 1305.90 & 1226.23 \\
\hline 20 & 1258.04 & 1202.28 & 874.74 & 1025.53 & 1514.88 & 1337.01 & 1225.16 \\
\hline 21 & 1463.87 & 1148.72 & 736.08 & 1055.62 & 1438.99 & 1355.38 & 1224.63 \\
\hline 22 & 1242.03 & 1033.87 & 1016.11 & 964.74 & 1510.67 & 1346.69 & 1221.40 \\
\hline 23 & 1523.73 & 1162.99 & 670.43 & 1112.94 & 1388.50 & 1236.06 & 1220.66 \\
\hline 24 & 1259.01 & 1220.40 & 930.46 & 951.66 & 1460.53 & 1258.14 & 1220.11 \\
\hline 25 & 1545.32 & 979.88 & 808.55 & 1046.71 & 1375.22 & 1300.69 & 1219.19 \\
\hline 26 & 1125.97 & 1183.81 & 913.12 & 1117.59 & 1487.70 & 1211.38 & 1218.55 \\
\hline 27 & 1158.38 & 1172.17 & 771.98 & 1002.97 & 1498.31 & 1300.82 & 1213.40 \\
\hline
\end{tabular}

${ }^{(1)}$ Estimates: $\hat{\mu}+\mathrm{g}$ : predicted genotypic value; and $\hat{\mu}+\mathrm{g}+\mathrm{ge}$, predicted genotypic value with capitalization of interaction with environments.

respectively, based on the average genotypic value in the environments $\left(\widehat{\mu}^{+} \mathrm{g}+\mathrm{gem}\right)$, (Table 4). It is observed that there was a flattening of the variance of the means obtained by the REML/BLUP method, when compared to the variance of the arithmetic means (phenotypic), causing the shrinkage effect. In this work, this fact is characteristic, because it is a balanced experiment in complete random blocks, without adjusting the means by retrieving the interblock information (DUARTE \& VENCOVSKY, 2001).

The expected genetic gain for these strains supplanted the performance of commercial cultivars 13 (BRS-Tumucumaque), 14 (BRS-Imponente) 26 (BRS-Itaim) and 27 (CB -27). ROCHA et al. (2017), obtained similar predicted gains when evaluating cowpea strains of semi-erect size for adaptability and stability and high grain yield in the Northeast region of Brazil using the REML / BLUP methodology.

The study of stability and adaptability to recommend the best strains in different test environments makes the magnitude of the effects resulting from the $\mathrm{G} \times \mathrm{E}$ interaction peculiar (CARVALHO et al., 2017). However, the adaptability and stability via estimates of the components of the means (BLUP) associated with the predicted genotypic value $(\widehat{\mu}+\mathrm{g})$ considering all environments, has the disadvantage of the lower capitalization of the genotype $\mathrm{x}$ environment interaction, culminating consequently in less predicted genetic gain (ROSADO et al., 2012; CARVALHO et al., 2016). 
When the environment selection methodology was used,predicted genotypic value with capitalization of interaction with environments $(\widehat{\mu}+\mathrm{g}$ + ge), it can be seen that strain4 (Bico-de-ouro 1-5-24) obtained the best performance in the environments (CAMBUCI 2016), (CAMBUCI 2017) and (Bom Jesus do Itabapoana 2017), on the other hand, strain6 (Pingo-de-ouro 1-5-4) was classified among the best performing in the environments (CAMBUCI 2016), (CAMBUCI 2018) and (Bom Jesus do Itabapoana 2018) respectively, the commercial cultivar 13 (BRSTumucumaque) had the third-best performance in the environment (CAMBUCI 2016). The cultivar 26 (BRS-Itaim) was classified as the one with the highest performance in the environment (CAMBUCI 2017) (Table 5).

The results observed through analysis by environment show that there was a change in classification in performance for grain yield of the selected strainsin the six environments evaluated individually, when compared to the selection methodology via estimates of the components of means (BLUP) associated with the predicted genotypic value $(\widehat{\mu}+\mathrm{g})$ considering the set of environments (Table 4).

In the strategy adopted in (Table 5), there was a greater predicted genetic gain, which can be attributed to the better capitalization of the effects of the genotype $x$ environment interaction in the selection by environment, compared with the selection for all environments (ROSADO et al., 2012; CARVALHO et al., 2016). Genotypic behavior can indicate a pattern of response to environmental stimuli through the study of estimates of adaptability and stability, depending on the oscillations of variations in the environment in question (Maia et al., 2009).

This change occurred due to high estimates of the variance of the genotype $\mathrm{x}$ environment interaction (23521.63) and the coefficient of determining the effects of the genotype $\mathrm{x}$ environment interaction (0.123), which imposes difficulty in recommending superior strains for the tested environments (TORRES et al., 2015; CARVALHO et al., 2017). It becomes evident, in this case, that the selection of strains of high productivity, predictability and adaptability must be made in a specific way (MAIA et al., 2009; TORRES et al., 2015).

The selection of the four best strains considering all environments (Table 4) allows us to infer that there was complete agreement with the HMRPGV methodology for grain yield. Strains4 (Bico-de-ouro 1-5-24), 6 (Pingo-de-Ouro 1-5-4) 5
(Pingo-de-Ouro 1-5-26) and 9 (Pingo-de-Ouro 1 -5-8) (Table 6) obtained grain productivity higher than the general genotypic average, demonstrating potential for selection in the cowpea breeding program.

Thus, it is possible to affirm that the averages of the environments associated with the predicted genotypic value $(\widehat{\mu}+\mathrm{g})$ produced results similar to the methods in which adaptability (RPGV) and adaptability and stability (HMRPGV) are capitalized, simultaneously. According to MAIA et al. (2009), this condition is associated with the selection of strains with greater stability and adaptability to the set of environments tested at a time.

In this sense, by the criterion of means of environments associated with the predicted genotypic value $(\widehat{\mu}+\mathrm{g})$ the four best strainsare repeated, 4 (Bico-de-ouro 1-5-24), 6 (Pingo-de-ouro 1-5 -4) 5 (Pingo-de-ouro 1-5-26), and 9 (Pingo-de-ouro 1-58 ), indicating that greater adaptive contribution in the six environments tested, also providing high predictability, that is, maintaining the superiority of grain yield in the various environments analyzed. These results are in agreement with (REGITANO et al., 2013), who studied the behaviour of highland rice genotypes in the state of São Paulo using the mixed model methodology (REML/BLUP).

The neutralization of environmental effects via BLUP plays an important role in the selection of genetic materials, with a focus on genotypic adaptability and stability, helping mainly to recommend new, more promising and productive cowpea cultivars (RESENDE, 2004). The maintenance of the ordering of the selected genotypes is evident for the selection strategies used in (Tables 4 and 6), reinforcing that it is possible to select strains with high yield, predictability and wide adaptability based on these results, with the exception of the strategy used in (Table 5), by characterize complex $\mathrm{G} \times \mathrm{E}$ interaction, causing incongruity in the ranking of genotypes.

\section{CONCLUSION}

Heritability based on the average of the 27 cowpea genotypes for grain production showed a low estimate, assuming an onerous condition in the selection process of the superior strains.

Strains 4 (Bico-de-Ouro 1-5-24), 6 (Pingode-Ouro 1-5-4) 5 (Pingo-de-Ouro 1-5-26) and 9 (Pingo-de-Ouro $1-5-8$ ) are promising for selection, with productivity above the general average of the experiment and simultaneous genetic gains for grain yield, adaptability and stability. 
Table 6 - Stability of genotypic values (HMGV), adaptability of genotypic values (RPGV), adaptability and stability of genotypic values (HMRPGV), genotypic value capitalizing on adaptability (RPGV $\mu$ ) and genotypic value penalized for instability and capitalized for adaptability (HMRPGV $\mu$ ) of 27 cowpea genotypes evaluated in six environments of the Northwest Fluminense region in 2016, 2017 and 2018

\begin{tabular}{|c|c|c|c|c|c|c|c|}
\hline Genotype & HMGV & Genotype & RPGV & $\mathrm{RPGV} \mu$ & Genotype & HMRPGV & HMRPGV $\mu$ \\
\hline 4 & 1301.01 & 4 & 1.088 & 1340.76 & 4 & 1.0821 & 1333.1644 \\
\hline 6 & 1264.75 & 6 & 1.072 & 1320.27 & 6 & 1.0665 & 1314.0035 \\
\hline 5 & 1263.64 & 5 & 1.055 & 1299.43 & 5 & 1.0521 & 1296.2001 \\
\hline 25 & 1243.36 & 9 & 1.038 & 1278.52 & 9 & 1.0332 & 1272.9525 \\
\hline 18 & 1236.35 & 25 & 1.033 & 1272.09 & 3 & 1.0308 & 1269.9379 \\
\hline 3 & 1236.09 & 3 & 1.032 & 1270.76 & 25 & 1.0275 & 1265.8614 \\
\hline 11 & 1235.85 & 2 & 1.028 & 1266.71 & 2 & 1.0247 & 1262.4514 \\
\hline 9 & 1235.79 & 11 & 1.028 & 1265.97 & 11 & 1.0247 & 1262.4007 \\
\hline 26 & 1221.31 & 18 & 1.026 & 1264.18 & 18 & 1.0188 & 1255.1437 \\
\hline 2 & 1217.02 & 26 & 1.014 & 1249.69 & 26 & 1.0084 & 1242.3428 \\
\hline 24 & 1205.36 & 24 & 1.009 & 1243.05 & 24 & 1.0074 & 1241.1303 \\
\hline 10 & 1203.15 & 13 & 1.004 & 1237.31 & 13 & 0.9999 & 1231.9498 \\
\hline 13 & 1199.03 & 10 & 0.999 & 1230.69 & 10 & 0.9945 & 1225.2948 \\
\hline 17 & 1194.57 & 7 & 0.996 & 1226.87 & 7 & 0.9932 & 1223.6044 \\
\hline 7 & 1188.68 & 17 & 0.994 & 1224.06 & 17 & 0.9925 & 1222.8014 \\
\hline 20 & 1186.12 & 8 & 0.993 & 1222.94 & 8 & 0.9863 & 1215.1752 \\
\hline 19 & 1184,69 & 19 & 0.989 & 1219.59 & 19 & 0.9843 & 1212.6778 \\
\hline 8 & 1168.17 & 20 & 0.986 & 1215.25 & 20 & 0.9836 & 1211.8704 \\
\hline 16 & 1163.88 & 16 & 0.974 & 1200.66 & 16 & 0.9713 & 1196.6359 \\
\hline 22 & 1153.62 & 23 & 0.971 & 1196.17 & 23 & 0.9664 & 1190.5696 \\
\hline 21 & 1148.82 & 22 & 0.966 & 1190.18 & 14 & 0.9576 & 1179.7505 \\
\hline 23 & 1148.34 & 14 & 0.964 & 1187.41 & 22 & 0.9567 & 1178.6774 \\
\hline 27 & 1148.31 & 21 & 0.960 & 1183.17 & 21 & 0.9544 & 1175.7844 \\
\hline 14 & 1133.32 & 27 & 0.957 & 1179.72 & 27 & 0.9505 & 1171.0578 \\
\hline 12 & 1119.41 & 1 & 0.948 & 1168.36 & 12 & 0.9405 & 1158.7712 \\
\hline 1 & 1103.22 & 12 & 0.947 & 1166.47 & 1 & 0.9355 & 1152.5400 \\
\hline 15 & 1100.58 & 15 & 0.929 & 1144.39 & 15 & 0.9226 & 1136.6522 \\
\hline
\end{tabular}

${ }^{(1)}$ MHRPGV, harmonic average of the relative performance of the genotypic values; and HMRPGV* $\mu$, refers to HMRPGV multiplied by the overall average across all environments.

\section{ACKNOWLEDGEMENT}

To the Coordenação de Aperfeiçoamento de Pessoal de Nível Superior (CAPES), Brasil - Finance code 001 and to the Fundação de Amparo à Pesquisa do Estado do Rio de Janeiro - FAPERJ.

\section{DECLARATION OF CONFLICT OF INTEREST}

The authors declare that there is no conflict of interest that could constitute an impediment to the publication of this article.

\section{AUTHOR CONTRIBUTIONS}

All authors contributed effectively to the conception of the manuscript idea, in the installation and conduction of experimental essays and data collection, in data analysis, writing and final review of the manuscript.

\section{REFERENCES}

ALVARES, C.A. et al. Köppen's climate classification map for Brazil. Meteorologische Zeitschrift, v.22, p.711-728, 2013. Available from: Available from: $<$ https://www.schweizerbart.de/ papers/metz/detail/22/82078/Koppen_s_climate_classification map for Brazil >. Accessed: May, 05, 2020. doi: 10.1127/0941$2948 / 2013 / 0507$.

AQUINO, D. A. L. et al. Adaptability and stability parameters for immature seeds and pods and mature dried seeds in cowpea genotypes in Brazil northeast. African Journal of Agricultural Research. v.11, 5071-5079, 2016. Available from: $<$ https://academicjournals.org/journal/AJAR/articleabstract/9B6B8E562140>. Accessed: Mar. 09, 2020. doi: 10.5897/ AJAR2016.11934. 
BARILI, L. D. et al. Adaptabilidade e estabilidade e a produtividade de grãos em cultivares de feijão preto recomendadas no Brasil nas últimas cinco décadas. Ciência Rural. v.45, 1980-1986, 2015. Available from: $<$ https://www.scielo.br/scielo.php?script=sci artt ext\&pid=S0103-84782015001101980>. Accessed: Mar. 17, 2020. doi: 10.1590/0103- 8478cr20141383.

BARROS, M. A. et al. Yield adaptability and stability of semi-prostrate cowpea genotypes. Pesq. agropec. Bras. v.48, 403-410, 2013. Available from: Available from: <https:// www.scielo.br/scielo.php? script $=$ sci arttext\&pid $=$ S0100204X2013000400008>. Accessed: Apr. 17,2020. doi: 10.1590/ S0100-204X2013000400008

CARVALHO, L. C. B. et al. Genotype x environment interaction in cowpea by mixed models. Revista Ciência Agronômica. v.48, 872-878, 2017. Available from: $<$ https://www.scielo.br/scielo.php ?pid=S180666902017000500872\&script $=$ sci_abstract\&tlng $=$ pt $>$. Accessed: May, 10, 2020. doi: 10.5935/1806-6690.20170103.

CARVALHO, L. P.de. et al. Use of REML/BLUP methodology for selecting cotton genotypes with higher adaptability and productive stability. Bragantia. v.75, 314-321, 2016. Available from: $<$ https:// www.scielo.br/scielo.php?script $=$ sci arttext\&pid $=$ S0006870520 16000300314\&lng=pt\&tlng=pt $>$. Accessed: Feb. 22, 2020. doi: $10.1590 / 1678-4499.275$

CHIORATO, A. F. et al. Prediction of genotypic values and estimate of genetic parameters in common bean. Brazilian Archives of Biology and Technology. v.51, 465-472, 2008. Available from: $<$ https://www.scielo.br/scielo.php?script $=$ sci arttext\&pid $=\mathrm{S} 151$ 689132008000300005\&lng=en\&tlng=en.>. Accessed: May, 19, 2020. doi:10.1590/S1516-300 89132008000300005.

CONAB. Companhia Nacional de Abastecimento. Acomp. safra bras. Grãos, Safra 2017/18. Brasília. v.5, p.1-148, 2018. Available from: <http://www.conab.gov.br>. Accessed: Mar. 27, 2020.

CRUZ, C. D. et al. Modelos biométricos aplicados ao melhoramento genético. Viçosa: Editora UFV, 2014. 668p.

DUARTE, J. B.; VENCOVSKY, R. Estimação e predição por modelo linear misto com ênfase na ordenação de médias de tratamentos genéticos. Scientia Agricola v.58, 109-117, 2001. Available from: $<$ https://www.scielo.br/scielo.php?script=sci_artte $\mathrm{xt} \& \mathrm{pid}=\mathrm{S} 010390162001000100017 \& \operatorname{lng}=\mathrm{pt} \& \mathrm{t} \operatorname{lng}=\mathrm{pt}>$. Accessed Sept. 21, 2020. doi: 10.1590/S0103-90162001000100017.

FAO. FAOSTAT. Crops. Cow peas, dry. (2018). Available from: $<$ http://faostat3.fao.org/browse/Q/QC/E > . Accessed: Mar. 09, 2020.

FILGUEIRA, F. A. R. Novo manual de olericultura: agrotecnologia moderna na produção e comercialização de hortaliças. Viçosa: Editora UFV, 2013. 3v.

FREIRE FILHO, F. R. Feijão-caupi no Brasil: produção, melhoramento genético, avanços e desafios. Embrapa Meio-Norte - Documentos, 2011. Available from: <https://www.alice.cnptia. embrapa.br/bitstream/doc/916831/1/feijaocaupi.pdf $>$. Accessed: Apr. 28, 2020.

MAIA, M.C.C. et al. Seleção simultânea para produção, adaptabilidade e estabilidade genotípicas em clones de cajueiro, via modelos mistos. Pesquisa Agropecuária Tropical. v.39, 43-50, 2009. Available from: $<$ https://www.redalyc.org/articulo.oa?id=253020183008>. Accessed: May, 07, 2020. doi: 10.5216/pat.v39i1.5704.
OLIVEIRA, L.A. et al. Performance of cowpea genotypes in the brazilian midwest using the bayesian additive main effects and multiplicative interaction model. Agronomy Journal. v.110, 147154, 2018. Available from: <https://acsess.onlinelibrary.wiley. com/doi/full/10.2134/agronj2017.03.0183. Accessed: May, 07, 2020. doi: 10.2134/agronj2017.03.0183.

PEREIRA, H. S. et al. Genetic variability for iron and zinc content in common bean lines and interaction with water availability. Genetics and Molecular Research. v.13, 6773-6785, 2014. Available from: <http://www.funpecrp.com.br/gmr/year2014/ vol13-3/pdf/gmr4236.pdf. Accessed: May, 07, 2020. doi: $10.4238 / 2014$.

RAMALHO, M. A. P. et al. Genética Quantitativa em Plantas Autógamas: aplicações ao melhoramento do feijoeiro. Goiânia: Editora UFG, 1993. 271p.

REGITANO, A. N. et al. Comportamento de genótipos de arroz de terras altas no estado de São Paulo. Revista Ciência Agronômica. V,44, 512-519, 2013. Available from: <https://www.scielo.br/ scielo.php?script $=$ sci arttext\&pid $=\mathrm{S} 1806-66902013000300013$. Accessed:Apr. 07, 2020 . doi: 10.1590/S1806-66902013000300013.

RESENDE, M. D. V.; DUARTE, J.B. Precisão e controle de qualidade em experimentos de avaliação de cultivares. Pesquisa Agropecuária Tropical. v.37, 182-194, 2007. Available from: $<$ https://www.redalyc.org/articulo.oa? id=253021631009. Accessed: Apr. 25, 2020.

RESENDE, M. D. V. Métodos estatísticos ótimos na análise de experimentos de campo. Colombo: Embrapa Florestas Documentos, 2004. Available from: $<$ https://www.infoteca.cnptia. embrapa.br/handle/doc/305549>. Accessed: May, 10, 2020.

RESENDE, M. D. V. SELEGENREML/BLUP: sistema estatístico e seleção genética computadorizada via modelos lineares mistos. Embrapa Florestas - Documentos, 2007. Available from: $<$ https://www.scienceopen.com/document?vid=98438678-3de545d3-96f3-a2552b9c9f2a>. Accessed: May, 12, 2020.

ROCHA, M. M. et al. Yield adaptability and stability of semiprostrate cowpea genotypes in the Northeast region of Brazil by REML/BLUP. Revista Ciência Agronômica. v.48, 879-888, 2017. Available from: <https://www.scielo.br/scielo.php?pid=S1806$66902017000500879 \&$ script $=$ sci abstract\&tlng=pt.>. Accessed: May, 13, 2020. doi: 10.5935/1806-6690.20170104.

RODRIGUES, E.V. et al. Selection of cowpea populations tolerant to water deficit by selection index. Revista Ciência Agronômica. v.48, 889-896, 2017. Available from: $<$ https://www. scielo.br/scielo.php?pid $=$ S180666902017000500889\&script $=$ sci abstract\&tlng=en.>. Accessed: May, 13, 2020. doi: 10.5935/18066690.20170105 .

ROSADO, A. M. et al. Seleção simultânea de clones de eucalipto de acordo com produtividade, estabilidade e adaptabilidade. Pesq. Agropec. Bras. v.47, 964-971, 2012. Available from: $<$ https://www.scielo.br/scielo.php?script=sci_arttext\&pid=S0100204X2012000700013.>. Accessed: May, 13, 2020. doi: 10.1590/ S0100-204X2012000700013.

SANTOS, J. A. S. et al. Desempenho agronômico e divergência genética entre genótipos de feijão-caupi cultivados no ecótono Cerrado/Pantanal. Bragantia. v.73, 377-382, 2014. Available from: <https://www.scielo.br/scielo.php?pid=S0006- 
87052014005000033\&script=sci_arttext. $>$. Accessed: Apr. 15, 2020. doi: $10.1590 / 1678-4499.0250$.

SANTOS, L. A. C. et al. Growth of cowpea cultivars in upland and lowland soils. Ambiência. v.13, 261-270, 2017. Available from: <https://revistas.unicentro.br/index.php/ambiencia/article/ view/2376/pdf. $>$. Accessed: May, 15, 2020. doi: 10.5935/ ambiencia.2017.01.17nt.

SANTOS, M. A. et al. Agronomic performance of maize intercropped with cowpea under different populations and plant arrangements in the semi-arid region of Minas Gerais. Revista Agroambiente. v.10, 201-208, 2016. Available from: <https:// revista.ufrr.br/agroambiente/article/view/3286>.Accessed: May, 10, 2020. doi: 10.18227/1982-8470ragro.v10i3.3286.

SANTOS, P. R. et al. Simultaneous selection for yield, stability, and adaptability of carioca and black beans. Pesq. Agropec. Bras. v.53,736-745, 2018. Available from: <https://www.scielo.br/scielo. php?script $=$ sci arttext\&pid $=\mathrm{S} 0100204 \mathrm{X} 2018000600736$. $>$.Acces sed: May, 07, 2020. doi: 10.1590/s0100-204x2018000600010.

SILVA, G. A. P. et al. Análise da adaptabilidade e estabilidade de produção em ensaios regionais de feijoeiro para o Estado de São Paulo. Revista Ceres. v.60, 59-65 2013. Available from: $\quad<$ https://www.scielo.br/scielo.php?pid=S0034 737X2013000100009\&script $=$ sci_arttext. $>$.Accessed: May, 08, 2020. doi: 10.1590/S0034-737X2013000100009.
SINGH, B. B.; et al., Recent progress in cowpea breeding. In: FATOCUN, C.A.; TARAWALI, S.A.; SINGH, B.B.; KORMAWA, P.M.; TAMÓ, M. Challenges and opportunities for enhancing sustainable cowpea production. Ibadan: IITA,2002. P.22-40.

TORRES, F. E. et al. Simultaneous selection for cowpea (Vigna unguiculata L.) genotypes with adaptability and yield stability using mixed models. Genetics and Molecular Research. v.15, 1-11 2016. Available from: <https://pdfs.semanticscholar.org/ d45f/d07795117bddf9893745532c48caa738c1d0.pdf.>. Accessed: May. 03, 2020. doi: 10.4238/gmr.15028272.

TORRES, F. E. et al. Genotype $\mathrm{x}$ environment interaction in semiprostrade cowpea genotypes via mixed models. Bragantia. v.74, 255-260, 2015. Available from: <https://www.scielo.br/ scielo.php?pid $=$ S000687052015000300255\&script=sci_arttext. $>$. Accessed: May, 21, 2020. doi: 10.1590/1678-4499.0099.

TORRES-FILHO, J. et al. Genotype by enviroment interaction in green cowpea. Revista Caatinga. v.30, 687-697, 2017. Available from: $\quad<$ https://www.scielo.br/scielo.php?script=sci arttext\&pi $\mathrm{d}=\mathrm{S} 1983-21252017000300687>$. Accessed: Feb. 08, 2020. doi: $10.1590 / 1983-21252017 \mathrm{v} 30 \mathrm{n} 317 \mathrm{rc}$

RESENDE, M. D. V. Software Selegen-REML/BLUP: a useful tool for plant breeding. Crop Breeding and Applied Biotechnology, v.16. p.330-339, 2016. Available from: <http:// dx.doi.org/10.1590/1984- 70332016v16n4a49>. Accessed: Jan. 23, 2018. doi: 10.1590/1984- 70332016v16n4a49. 